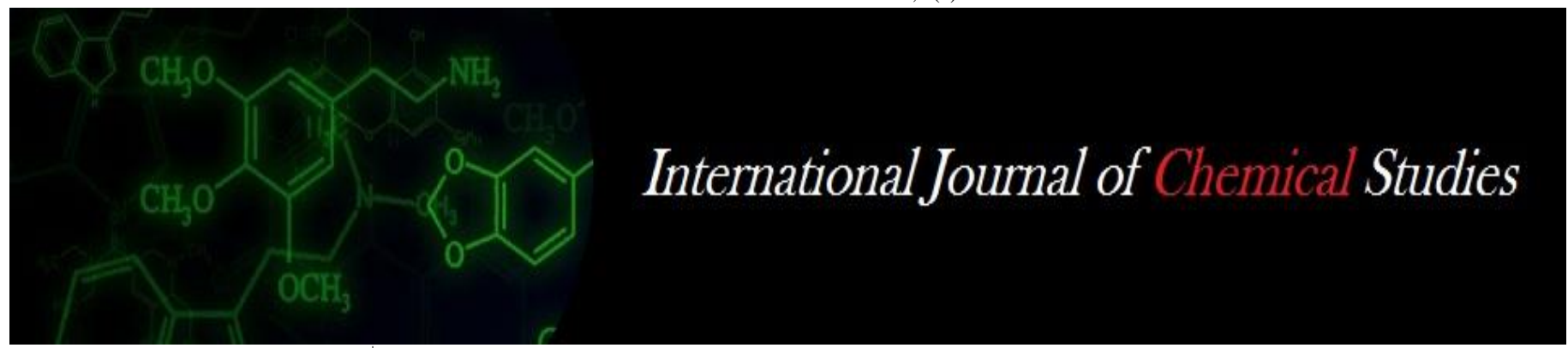

P-ISSN: 2349-8528

E-ISSN: 2321-4902

www.chemijournal.com

IJCS 2020; 8(6): 2010-2016

(C) 2020 IJCS

Received: 02-08-2020

Accepted: 09-09-2020

Kandrekula Vasu Gangadhar M.Sc. Research Scholar, Department of Agronomy, School of Agriculture, Lovely Professional University, Jalandhar, Punjab, India
Corresponding Author: Kandrekula Vasu Gangadhar M.Sc. Research Scholar, Department of Agronomy, School of Agriculture, Lovely Professional University, Jalandhar, Punjab, India

\section{Response of phosphorous and growth regulators on oil seed crops: A review}

\author{
Kandrekula Vasu Gangadhar
}

DOI: https://doi.org/10.22271/chemi.2020.v8.i6ac.11059

\begin{abstract}
Oilseeds are rich in protein, and additionally, they contain a high level of fat. Hence, they're not only good sources of protein but also concentrated sources of energy. The proteins in oilseeds are often fed either as a part of the oil-intact seed or as a meal from which the oil has been removed. For better production of oilseeds, it's compulsory to specialize in the appliance of various essential nutrients within the sort of fertilizers. We've to focus on the foremost important oilseed crops within the world. As practices, a properly balanced supply of phosphorous and application of plant growth regulators (PGRs) is one among the foremost important factors to extend higher yield and oil content in oilseed crops. PGRs play a crucial role in mitigating stress, increasing flower set, yield, and physiological efficiency of the crop. Many field experiments conducted on different oilseed crops from which it is often reported that the optimum level of phosphorous and growth regulators significantly enhanced the expansion, yield, oil content, and protein in oilseeds. This paper directly focuses on the role of phosphorus and growth regulators of naphthalene acetic acid and salicylic acid in improving oilseed crop production.
\end{abstract}

Keywords: Phosphorous, growth regulators, naphthalene acetic acid, salicylic acid, oilseeds, growth and yield attributes

\section{Introduction}

India is one of the main oilseed grower and importer of edible oils. India's oil economy is the world's fourth-largest economy after the USA, China \& Brazil. Oilseed represents $13 \%$ of the Gross Cropped Area, 3\% of the Gross National Product, and 10\% of all agricultural commodities. (Pooja K. Patel et al., 2019) ${ }^{[39]}$. Oilseeds are leading suppliers of superior quality and specialty vegetable oils to nutritional products, natural food, and premium dish worldwide. (Muhammad Farhan Sarwar et al., 2013) ${ }^{[42]}$. In India, oil seeds are cultivated over an area of 24.65 million hectares with a production of 31.31 million tonnes (Anon, 2018). Groundnut, sesame, rapeseed mustard, Niger, castor, linseed, and safflower oilseed crops are cultivated for an extended time, and soybean and sunflower are recently introduced in India. Whereas sarson, toria, and taramira are rapeseeds, the Raya is mustard. The country's oilseed supplies depend totally on seven edible and two non-edible oilseeds (castor and linseed). (A.L. Singh 1999) ${ }^{[24]}$. Due to high protein and vitamin A or oil, oilseeds add substantial nutritional value to the diet. Oilseeds, are the most important source of vegetable oils albeit most oil-bearing tree fruits provide the very best oil yields (olive, coconut and palm trees) (Sarwar, 2013) ${ }^{[42]}$. Oilseeds also are utilized in animal feed due to their high protein content. Their seeds contain energy primarily as oil for the sprouting embryo, compared to cereals that contain energy within the starch form (McKevith, 2005) ${ }^{[30]}$.

India is the main contributor to the worldwide production of castor $(79.6 \%)$ and also contributes significantly to the assembly of sesame (31.2\%) and groundnut $(25.1 \%)$. it is the second-largest groundnut and rapeseed- mustard manufacturer. Oilseed crops cover an area of roughly 28.53 million hectares in India, with an annual production of 32.88 million tonnes on annual (Ministry of Agriculture, GOI, 2013-14). Oil and fats are important parts of the human diet and quite $90 \%$ of the world's production from vegetables, animals, and marine sources is employed as food or as an ingredient in food products. Edible vegetable oils are foodstuffs consisting mainly of fatty acid glycerides that are derived only from vegetable sources. They contain small amount of other lipids like phosphatides, of unsaponifiable constituents and free Fatty acids naturally present within the fat or oil. 
(Praduman Yadav et al., 2018) [51] Additionally, to oilseed crops, secondary sources of edible oils like rice bran, cottonseed, coconut, vegetable oil, and oil palm oilseeds also are popular in India. In oilseeds quality criteria are carboxylic acid composition, tocopherols, phenolic compounds of the seed oil, and therefore, the intended use of the oil. Oilseeds form a crucial component of the human diet in Asia and therefore, the Pacific. Oilseeds are grown on diverse soils mostly under unirrigated and fewer than ideal conditions and plant nutrients are one among the foremost important constraints on their growth and yield (Reid 1981).

\section{Role of phosphorous}

To increase this production level of oilseed crops, it's necessary to manage improved technology packages, balanced application of Phosphorous is also a crucial element, and it plays an important role within the stability of edible oil within the country to unravel domestic requirements. Phosphorus (P) is an important macro-nutrient, necessary for the normal growth and development of upper plants. It's a component of several macro-molecules, like nucleic acids and phospholipid, and forms phosphate esters as intermediates within the metabolic pathways, and in energy-rich metabolites or coenzymes; thus, it plays an important role in the cellular structure and energy metabolism (Hawkesford et al., 2012) [18]. The United Nations (UN)'s Food and Agricultural Organization (FAO) estimates that plants only absorb approximately $20-30 \%$ of $\mathrm{P}$ in applied fertilizers annually (Syers et al., 2008) ${ }^{[46]}$. Phosphorus is a crucial constituent of energy-rich compounds, including ATP (ATP), cytosine triphosphate (CTP), guanosine triphosphate (GTP), uridine triphosphate (UTP), phosphoenolpyruvate, and other phosphorylated intermediate compounds. Hence, it supplies energy to drive various cellular endergonic processes. Being a constituent of nucleic acids (DNA, RNA), it's essential for copy and protein synthesis. To take care of its role under phosphate (Pi-deprived conditions), plants undergo various morphological, physiological, and biochemical adaptations. These include alterations in root architecture, the formation of cluster roots, shoot development, organic acid exudation, and alternative glycolysis and respiratory pathways (Vance et al., 2003) [49]. Phosphorous may be a constituent of several essential cell components like nucleotides, nucleic acids, and phospholipids. It's particularly important in the early growth stages. Phosphorous plays an important role within the energy storage and transfer within the sort of AMP, ATP, NADP or NADPH (Tandon, 1987).

Plant nutrition may be a key input to extend the productivity of soybean seed crop. Out of several nutrients provided to plants, phosphorus may be a major and essential nutrient for better plant growth and yield as this crop is exhaustive in nature and requires more energy. It's involved in wide selection of plant processes from permitting cellular division to development of excellent rootage. It regulates pod setting, seed formation, development and protein synthesis. The enhancement of symbiotic $\mathrm{N}$-fixation by root nodules as a results of phosphorus nutrition is supported due to high phosphorus requirement of the Bacteroides. (Sandeep kumar et al., 2017). Soybean consistency is affected by the availability of nutrients and phosphorus has a beneficial effect on the content of oil and protein (Gaydou and Arrivets, 1983) [15]. Very high values of soil phosphate can depress the content of seed protein and oil or induce deficiencies of zinc and iron (Weiss, 1983). Additionally, to proper dose of phosphorus, an appropriate sort of groundnut should be identified to extend its production. The yield of groundnut could also be increased through appropriate combination of levels of phosphorus (SJ Mouri 2018) ${ }^{[33]}$. Due to its high uptake of nutrients, sunflower responds alright to applied nutrients. Phosphorous applications have improved sunflower seed yield by 50 percent. (Chorey and Thosar, 1997) ${ }^{[7]}$. among the various nutrients required by sunflower, nitrogen and phosphorus are the first limiting nutrients under most environments (Devidayal and Agarwal, 1998; Baldev Raj et al., 1999). Further this may fulfil the demand of everincreasing edible oil. In spite of such a significance the productivity of Niger crop is extremely low which can be enhanced by adequate and integrated supply of nutrient especially phosphorus, because being oilseed crop Niger respond well to phosphorus, hence yield potential of this crop are often improved through adequate supply of phosphorus (NS Lende 2017) ${ }^{[28]}$.

Phosphorous is a fascinating plant nutrient, it is involved in a wide range of plant processes from permitting cell division to the development of a good root system and ensure timely uniform repining of the crop. It is needed mostly to be young fast-growing tissues and perform a number of functions related to growth, development, photosynthesis, and utilization of carbohydrates (F.C. Oad et al., 2001 [38]. It is evident, therefore that oilseed requires a high $\mathrm{P}$-supply in order to generate a high content of high oil-containing energy. It is evident, therefore that oilseed requires a high P-supply in order to generate a high content of high oil-containing energy. Indian soils that are usually low to medium in phosphorous accessible and the availability of "P" by fertilizers is still below the optimum level due to very high phosphatic fertilizer prices. Phosphorous in growing plants is quite mobile. When the deficiency of phosphorous starts to develop in a plant, the absorbed phosphorous migrates from older to young plant parts. Symptoms of phosphorous deficiency, therefore, appear first on older leaves, gradually bluish-green to reddish color develops which can lead to stunted growth and death of the plant. If the phosphorous deficiency appears, then soil and plant tests should be done and fertilizer must be added by rectifying and shortcomings in fertilizer practices particularly while aiming for high yield and profits (Tandon, 1987).

\section{Role of plant growth regulators}

Plant hormones are naturally produced by plants and are important for the control of their own growth. They function by regulating or altering the growth processes of plants, such as the formation of leaves and flowers, stem elongation, fruit production and ripening. In modern agriculture, people have established the advantages of extending the utilization of plant hormones to manage growth of other plants (Abubakar Siddik et al., 2016) ${ }^{[45]}$. Plant growth regulators (PGRs) which may improve the physiological efficiencies of plant could play a major role in increasing crop yield and quality, when applied as foliar spray at proper crop growth stage in optimum concentration. Plant growth regulators (PGRs) have the capacity to change every phase of plant growth spanning from seed germination to crop maturity. Since most plant growth and seed development processes are regulated by natural plant hormones, many of those processes could be manipulated either by altering the endogenous hormone level or by changing the capacity of the plant to respond to its natural hormones. It's accepted that plant hormones are involved in grain filling and seed development (Al- Jobori, 2012) ${ }^{[2]}$. Plant growth promoters and growth retardants have great potential 
in increasing agricultural production and help in removing many of the barriers imposed by genetics and environment. They play a crucial role in mitigating stress, increasing flower set, yield and physiological efficiency of the crop (P Prasanth Kumar and Dr. Suchit A John 2018) ${ }^{[26]}$. The process is physiological and biochemical and thus increases the yield of the crop. The localized application of some plant growth regulators is reported to possess profound effects on assimilate partitioning, enhancing the crop productivity plant growth regulators are effective on several crop plants to balance the source sink relationship and manipulate a spread of growth and developmental phenomena in various crops (S. Behera 2017) ${ }^{[6]}$.

The application of NAA can increase fruit setting ratio, prevent fruit dropping, promote flower sex ratio (Rahul A Kengare et al., 2018). The most role of NAA rests with the efficient transport of sugars from the photosynthesizing parts of the plant to the developing grains. The NAA enhance endogenous levels of PGRs including gibberellins because auxin is important to gibberellins biosynthesis, which affect growth, physiological attributes and eventually yield in

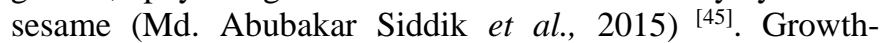
stimulating chemicals are wont to modify the growth and development of the mustard plant to extend its yield and also to enhance the standard of products. Naphthalene ethanoic acid (NAA) is a crucial synthetic auxin (Yamamoto \& Yamamoto, 1998) ${ }^{[52]}$. NAA is synthetic auxin with identical properties to that of present auxin i.e., IAA in plant. Auxin in low concentration promotes cell elongation i.e., growth, but in higher concentration it inhibits the growth. The increase in production of linseed is only being possible due to increase in area under crop and by applying growth promoting substances like cow urine and NAA (Kekita H. Chute et al., 2017) ${ }^{[8]}$. NAA (Naphthalene Acetic Acid) is the synthetic auxin with the identical properties to that naturally occurring auxin. It prevents formation of abscission layer and thereby flower drop. It had been observed that the growth regulators are involved within the direct transport of assimilates from source to sink (Sharma et al., 1989) ${ }^{[29]}$.

Salicylic acid (SA) acts as a possible non-enzymatic antioxidant the maximum amount as plant phytohormone, playing a crucial role in regulating a variety of plant physiological processes (Fariduddin et al., 2003; Raskin, 1992) ${ }^{[14]}$. SA is one of the numerous phenolic compounds, containing an aromatic ring with a hydroxyl or its derivatives, found in plants. There has been considerable speculation that phenolics generally function as plant growth regulators (Aberg, 1981) ${ }^{[1]}$. salicylic acid (SA) as a potent signaling molecule in plants is involved in defense mechanisms by regulating physiological and biochemical functions and has diverse effects on tolerance to biotic and abiotic stress factors (Gunes et al., 2007; Nazar et al., 2011) ${ }^{[16,36]}$. Exogenously supplied SA was shown to affect a large form of processes in plants, including stomatal closure, seed germination, fruit yield, and glycolysis (Cutt et al., 1992) ${ }^{[9]}$. 2-hydroxybenzoic acid is involved in many plant physiological processes like photosynthesis, transpiration, nutrient uptake, chlorophyll, and protein synthesis. When applied at physiological concentration, foliar application of 2-hydroxybenzoic acid exerted a major effect on plant growth and metabolism and thus acted together with the substances controlling plant growths. Salicylic acid hormone and plays diverse physiological roles in plants including thermogenesis generate a good range of metabolic and physiological responses thereby affecting their growth and development (Hayat et al.,
2010) [14, 19]. 2-hydroxybenzoic acid plays diverse physiological roles in plants which incorporates plant growth, thermogenesis, flower induction, nutrient uptake, ethylene biosynthesis, stomatal movements, photosynthesis, and enzyme activities (Hayat \& Ahmed, 2007) [14, 19]. Further, salicylic acid also plays a crucial role in the regulation of varied plant physiological processes like photosynthesis or non-enzymatic antioxidant (ElKhallal et al., 2009; Salarizdah et al., 2012). The concentration of glucosinolates in their leaves was increased by applying SA to oilseed rape plants. The group of thioglucosides present in cruciferous plants is glucosinolates. When tissues are damaged, glucosinolates are hydrolyzed and release various products which are thought to contribute to the plant's defense against microorganisms and pests. (Kiddle et al., 1994) [25] demonstrated a rise in secondary metabolite content in response to salicylic acid.

\section{Impact of phosphorous on growth attributes in oilseeds}

F.C. Oad et al., (2001) ${ }^{[38]}$ detailed that in Brassica, the use of 90:60:30 or 120:80:40 NPK kg per ha shows most elevated plant tallness and number of Branches per plant was noticed contrast with lower fertilizer doses of 30:20:10 and 60:40:20. Khanam. M et al., (2016) ${ }^{[23]}$ founded that in soya bean, Combined impact of $\mathrm{P}$ and $\mathrm{K}$ fertilizers although the two of them assumed a significant function on growth attributes. The use of Triple Super Phosphate (TSP) at $175 \mathrm{~kg} / \mathrm{ha}$ and MOP at $120 \mathrm{~kg} / \mathrm{ha}$ had critical impact on number of nodules and most noteworthy number of pods/plants was noticed. Mouri SJ et al., (2018) ${ }^{[33]}$ announced that in Ground nut, the utilization of Phosphorous at $60 \mathrm{~kg} / \mathrm{ha}$ had huge increment on development of the on growth attributes that the highest value of all the parameters like leaf area index, dry matter, number of primary branches/plant, number of secondary branches/ plant, number of pegs/ plant was recorded contrasted with 40, 20 and $0 \mathrm{~kg}$ P/ha. Myo Win et al., (2010) ${ }^{[50]}$ revealed that in soya bean, Phosphorus use efficiencies and dry matter accumulation in the soybean assortments considered expanded with increasing phosphorus supplement application up to the amount of 1.0 $\mathrm{mM}$ P. Increasing the outer phosphorous focus to more than $1.0 \mathrm{mM}$, caused a decrease in P-usage efficiencies, as the $\mathrm{P}$ fixation in the tissues expanded with no extra development. An expansion in P-use efficiencies was related with an increment in the overall extents of dry matter $\mathrm{P}$ in shoot tissues. Hina Malhotra et al., (2018) [29] detailed that, Phosphorous is a significant factor for seed germination and improved seedling life, increase growth attributes plant tallness, leaf area, leaf number and shoot dry biomass, Flower and Seed Formation.

\section{Impact of phosphorous on yield and oil content attributes in oilseeds}

F.C. Oad et al., (2001) ${ }^{[38]}$ announced that in Brassica, the use of 90:60:30 or 120:80:40 NPK kg per ha shows highest number of siliquae, seed weight, seed index and oil contented of mustard crop was recorded. And indicated productivity for increasing greatest yield ascribes with the use of higher fertilizer dosage contrast with lower fertilizer dosages of 30:20:10 and 60:40:20. Thavaprakash, N et al., (2002) [47] revealed that in sunflower, Higher seed yields of sunflower acquired in the treatment getting N/P proportion of 1.0 with $2.00 \mathrm{~N}$ : $2.00 \mathrm{P}: 1.00 \mathrm{~K}$ fertilizer level produced larger heads, more head weight at harvest, more seed weight plant/ha and more 1000- seed weight as with the treatments receiving N/P ratio of $>1.0$ with $2.00 \mathrm{~N}$ : $1.25 \mathrm{P}: 1.00 \mathrm{~K}$ fertilizer level. Khanam. M et al., (2016) ${ }^{[23]}$ detailed that in soya bean, 
Combined impact of $\mathrm{P}$ and $\mathrm{K}$ fertilizers enhanced the number of filled pods/ plant, The maximum seeds/pod, Pod length (cm), seed index, seed yield, Stover yield (t ha-1), Biological yield (t ha-1) and Harvest index (\%) of soybean respectively. Mouri SJ et al., (2018) ${ }^{[33]}$ revealed that in Ground nut, the impact of Phosphorous at $60 \mathrm{~kg} / \mathrm{ha}$ shows critical increase number of total pods/ plant, weight of 100-pods, weight of 100-seeds, shelling percentage, pod yield, seed yield, Stover yield and harvest index expanded continuously with the expanding level of phosphorus manure at $60 \mathrm{~kg} \mathrm{P} / \mathrm{ha}$. Myo Win et al., (2010) ${ }^{[50]}$ detailed that in soya bean, the use of 1.0 and $2.0 \mathrm{mM} \mathrm{P}$ caused critical declines in the seed protein content by 4 and $5 \%$, individually, when contrasted with that of 0.5 mM P. Sandeep Kumar et al., (2017) announced that in soya bean, Application of $90 \mathrm{~kg}$ P2O5/ha with $45 \mathrm{~kg}$ S/ha recorded highest seed and Stover yield in soybean. Phosphorus and sulphur application significantly huge expansion in the supplement convergence of full scale just as micronutrients in seed. On the utilization of $90 \mathrm{~kg} \mathrm{P} 2 \mathrm{O5} / \mathrm{ha}$, most noteworthy supplement substance of N, P, K. Ca, Mg. At more significant levels of phosphorus application, $\mathrm{Zn}$ content of seed reduced and it was most noteworthy at $30 \mathrm{~kg}$ P2O5 ha-1. With utilization of $45 \mathrm{~kg} \mathrm{~S}$ ha-1, the substance of $\mathrm{N}, \mathrm{P}, \mathrm{K}, \mathrm{Ca}, \mathrm{Mg}$ and $\mathrm{S}$ was expanded. Shubhangi J. Dhage et al., (2014) detailed that the soybean seed and straw yield expanded altogether because of utilization of phosphorus. The utilization of $90 \mathrm{~kg} \mathrm{P2O5/ha} \mathrm{indicated} \mathrm{fundamentally} \mathrm{better}$ outcome over rest of the treatment aside from crop getting 60 $\mathrm{kg} \mathrm{P} 2 \mathrm{O} 5 / \mathrm{ha}$. The use of 90 and $60 \mathrm{~kg}$ P2O5 demonstrated most elevated and practically same convergence of protein and in pooled. Increment in oil content was to the tune of $2 \%$ to $7.2 \%$ because of utilization of 30 to $90 \mathrm{~kg} \mathrm{P}$ over control. Soodabeh Bastani et al., (2017) ${ }^{[4]}$ detailed that in foliar application of oilseed rape plant had preferences over root application maintaining root $\mathrm{P}$ acquisition capacity from soil however, In addition to the reduction in fruit yield, a lower recovery rate was observed for foliar-applied $\mathrm{P}$ at the reproductive level. According to these results, as indicated by these outcomes, foliar P fertigation in oilseed rape plants is suggested distinctly at before flowering stages. Lende NS et al., (2017) [28] announced that in Niger, the treatment combination of N@40 kg/ha and P@20 kg/ha done by blend of SSP+PSB maximum number of capitulate per plant and number of seeds per capitula were recorded. Use of phosphorus expanded the photosynthetic and microbial activities and movement of photosynthates, which brought about higher seed yield. The treatment blend of $\mathrm{N} @ 40 \mathrm{~kg} / \mathrm{ha}$ and P@20 kg/ha through SSP+PSB gave fundamentally higher seed yield and highest $\mathrm{B}: \mathrm{C}$ ratio.

\section{Role of Naphthalene acetic acid in increasing growth and flowering ascribes in oilseed crops}

P Prasanth Kumar and Dr. Suchit A John (2018) ${ }^{[26]}$ presumed that impact of plant growth promoters and growth retardants, GA3, NAA, Cycocel and Ethrel at various concentrations on mustard. The maximum plant height $(\mathrm{cm})$ and highest growth rate was recorded at 90 DAS in NAA@ 100ppm compared with different treatments and control. It very well may be utilized as a successful plant growth regulator advertiser for the growth and development. The utilization of growth retardants i.e., Compared with control, Cycocel @ 300ppm suggested a decrease in plant stature $(\mathrm{cm})$. The higher number of branches per plant, number of leaves per plant, total dry matter content (gm) per plant was recorded by Cycocel @ $100,200,300 \mathrm{ppm}$ as compared to control. The utilization of
Ethrel @ 100, 200 and 300ppm has recorded higher growth rate compared with control. Md. Abubakar Siddik et al., $(2015)^{[45]}$ revealed that, the morpho-physiological parameters, utilization of 50 ppm NAA essentially expanded morphological characters-plant height, leaf number/plant, branch number/plant, fresh and dry weight of shoot and root other than leaf and branch number/plant at 30 and 40 DAS. Ferdousi Begum et al., (2018) ${ }^{[5]}$ detailed that, the naphthalene acitic acid fundamentally affected the biochemical character of rapeseed oil. 70 ppm NAA ha-1 confirmed the most important chlorophyll substance of rapeseed leaves at 50 days after emergence. The most extreme nitrogen content in the leaves was likewise found in a similar NAA level at 45 DAE. Kekita H. Chute et al., (2017) ${ }^{[8]}$ announced that in linseed, linseed, foliar sprays of cow urine and NAA showed their significance over control. Treatment $(4 \%$ cow urine $+50 \mathrm{ppm}$ NAA) followed by (6\% cow urine $+50 \mathrm{ppm}$ NAA) significantly increased chlorophyll content in leaves, leaf nitrogen content, leaf phosphorus content and leaf potassium content. Shanker Lal Khaswa et al., (2014) ${ }^{[24]}$ revealed that $40 \mathrm{~kg}$ P2O5/ha, SSP and foliar spray of $100 \mathrm{ppm}$ NAA resulted in sustained higher soybean productivity due to enhancement in phosphorous use efficiency that resulted in significantly higher pooled plant height, number of branches per plant. Utilization of PGRs resulted in significantly early setting of $50 \%$ flowering and significant improvement in performance of various growth parameters.

\section{Role of Naphthalene acetic acid in increasing yield and oil content ascribes in oilseed crops}

Rahul A Kengare et al., (2018) reported that in sunflower the foliar sprays of PGR's were given at the time of $50 \%$ flowering and seed formation. The impact of boron $(0.2 \%)$, Kinetin (200 ppm) and TIBA (240 ppm) shows more Total number of filled seeds/head, Total number of seeds/head, Seed Filling Percentage (\%), Head Diameter (cm), Yield q/ha, Harvest Index (\%) and Oil Content (\%) compared to NAA (50 ppm). Md. Abubakar Siddik et al., (2015) ${ }^{[45]}$ reported that, as morphological parameters NAA also significantly improves yield contributing characters of sesame the number of pods/plant, diameter and length of pod, seed weight/plant/plot, thousand seed weight compared to without NAA. Foliar application of 50 ppm NAA would be helpful to enhance the seed yield of sesame. Ferdousi Begum et al., (2018) [5] announced that, an estimation of 70 ppm NAA confirmed the highest oil content the most elevated oil content. A value of 70 ppm NAA also showed the highest oil content. The minimum acid, peroxide and saponification values were observed in $70 \mathrm{ppm}$ NAA. The same treatment also showed the highest iodine value. By decreasing the NAA level, nonessential fatty acids were increased in the mustard plant, while necessary fatty acids were highest in $70 \mathrm{ppm}$ NAA/ha. So, $70 \mathrm{ppm}$ NAA/ha can be used to grow quality mustard. Kekita H. Chute et al., (2017) ${ }^{[8]}$ revealed that in linseed, foliar sprays of cow urine and NAA showed their significance over control. Treatment $(4 \%$ cow urine $+50 \mathrm{ppm}$ NAA) followed by (6\% cow urine $+50 \mathrm{ppm}$ NAA) significantly increased oil content in seed, number of capsules/plant, number of seeds/capsules, test weight, seed yield/plant (g) and seed yield/plot (kg). Minakshi R. et al., (2017) [31] revealed that the use of $350 \mathrm{ppm}$ humic Acid through vermicompost wash +50 ppm NAA followed by 300 ppm humic acid through vermicompost wash +50 ppm NAA in linseed had significant promotive impact on oil content in seed, number of capsules plant-1, number of seeds capsules-1, 
1000 seed weight, seed yield/plant/ plot/ha when compared with the control treatment. Hence, the two foliar sprays of 350 ppm HA through VCW + 50 ppm NAA at 35 and 55 DAS can be considered as the successful supplement the nutrient management treatment. Shanker Lal Khaswa et al., (2014) ${ }^{[24]}$ reported that $40 \mathrm{~kg} \mathrm{P} 2 \mathrm{O} 5 / \mathrm{ha}, \mathrm{SSP}$ and foliar spray of $100 \mathrm{ppm}$ NAA resulted in higher oil content, oil yield, seed protein yield, grain yield and Stover yield. Use of PGRs resulted in significantly prolonged crop maturity period besides significant improvement in performance of various dry matter productivity and quality parameters of soybean. Siddik et al., (2016) [45] stated that in sesame, seed yield and yield contributing parameters of sesame are positively correlated with $\mathrm{N}$ and NAA application. The combined use of $60 \mathrm{~kg}$ $\mathrm{N} / \mathrm{ha}$ and $50 \mathrm{ppm}$ NAA along with recommended doses of other fertilizer would be beneficial to increase the seed yield of sesame.

\section{Role of salicylic acid on growth qualities in oilseed crops} Faizan Ullah et al., (2012) [48] concluded that in canola (Brassica napus L.) the effect of SA appears to be mediated by improving photosynthetic pigments consequently enhancing photosynthesis, economizing the water budget as obvious by increased Leaf relative water content and by augmenting osmoregulating proline production and preventing proteins from getting degraded. EL Sabagh et al., (2017) ${ }^{[13]}$ reported that in canola, the irrigation intervals have a significant influence on growth traits. Application of antioxidants salicylic acid 200 ppm, Ascorbic acid 200 ppm had a significant increase on the growth attributes of plant height, a number of branches /plant, and Relative water content (\%). S. H. Jadhav et al., (2011) ${ }^{[8]}$ concluded that in groundnut, application of Salicylic acid with $50 \mathrm{ppm}$ concentration showed significant germination in all groundnut cultivars. SA also showed a positive impact on root and shoot growth parameters in groundnut. Siddhi Gupta et al., (2017) ${ }^{\text {[17] }}$ revealed that in soybean, there was an improved inhibitory impact on seed germination percentage, root length, shoot length, tolerance index, fresh weight, and dry weight of soybean seedlings from the application of $0.5 \mathrm{mM}$ SA with lead concentrations. SA mitigated the adverse effects of lead and zinc stress on the growth parameters of soybean plants in the early seedlings' growth stage. Refat A. Youssef et al., (2017) ${ }^{[53]}$ reported that in sunflower, increasing the rate of salicylic acid from 0 to $1.4 \mathrm{mM}$ led to increasing significantly leaf area, plant height of sunflower plants under all levels of soil salinity. High physiological composition values (chlorophyll $\mathrm{a}$ and $\mathrm{b}$, carotenoids) were administered with high salicylic acid levels of $1.4 \mathrm{mM}$. Mona G. Dawood et al., (2019) ${ }^{[10]}$ reported that in flax, Salicylic acid was the most efficient phenolic acids in increasing growth parameters. And various improving biochemical parameters, where salicylic acid at $100 \mathrm{mg} / \mathrm{l}$ was the most effective treatment. Improved growth parameters, photosynthetic pigments, IAA, phenolic material with the application of various phenolic acids. Nitish Sharma et al., (2018) ${ }^{[29]}$ stated that in mustard Brassica juncea (L.) Foliar application of plant growth regulators significantly improved the total chlorophyll contents in leaf up to 60 DAS and after 60 DAS the declining trend was recorded in total chlorophyll content in leaf. Total chlorophyll content in leaf and maximum increase in the number of flowers per plant was observed in GA3 $50 \mathrm{ppm}$ followed by salicylic acid $0.5 \mathrm{mM}$ and Minimum kinetin increase of 25 ppm over control at the full blooming stage. S Muthulakshmi et al., (2017) ${ }^{[35]}$ reported that Salicylic acid which is a secondary plant product performs important actions in the growth and development processes of plants. In plants, it is an important signaling molecule and is involved in eliciting responses to biotic and abiotic stress. Salicylic acid has been studied as a phytohormone, which modulates many plant responses. Therefore, SA acts as a standard phytohormone for plants.

\section{Role of Salicylic acid on yield qualities in oilseed crops}

R. Nazar et al., (2015) ${ }^{[37]}$ revealed that SA application by foliar spray at a concentration of $0.5 \mathrm{mM}$ could protect the mustard (Brassica juncea L.). Application of $0.5 \mathrm{mM}$ SA under drought stress conditions significantly increased proline content by $168.6 \%$ compared with control. Under no-stress condition $0.5 \mathrm{mM}$, SA increased proline accumulation of $67.2 \%$ in comparison to control. Sarita muhal et al., (2014) ${ }^{[34]}$ reported that in Brassica juncea var. Bio- 902 sown during SMW 41 found better yield compare to SMW 43 and SMW 45 sown crops and also a foliar spray of $100 \mathrm{ppm}$ SA increased seed yield of Brassica. Faizan Ullah et al., (2012) ${ }^{[48]}$ concluded that in canola (Brassica napus L.) the effect of Salicylic Acid improved seed proteins under drought stress. EL Sabagh et al., (2017) ${ }^{[13]}$ reported that in canola, the irrigation intervals have a significant influence on yield and quality trials. Application of antioxidants salicylic acid 200 ppm, Ascorbic acid $200 \mathrm{ppm}$ had a significant increase on the seed yield and quality traits of canola under water-deficient conditions. The maximum seed yield/ha was achieved by the applications of a combination of both antioxidants' salicylic acid 200ppm and Ascorbic acid 200ppm with irrigation every 25 days. Refat A. Youssef et al., (2017) ${ }^{[53]}$ reported that in sunflower, increasing the rate of salicylic acid from 0 to 1.4 $\mathrm{mM}$ led to increasing significantly all yield components of sunflower plants under all levels of soil salinity. Under high levels of salicylic acid $1.4 \mathrm{mM}$ was given high values of physiological compositions (total carbohydrate, protein content, and proline). Mona G. Dawood et al., (2019) ${ }^{[10]}$ reported that in flax, Salicylic acid was the most efficient phenolic acids in increasing yield parameters. Application of different phenolic acids increased seed yield, and yield components as well as oil and carbohydrate percentages in the yielded seeds.

\section{Conclusion}

It is concluded that phosphorous and growth regulators of Naphthalene acetic acid and salicylic acid play an important role to increase the yield of oilseed crops. Phosphorus is considered a crucial component and has proven to be vital for the development, growth, and productivity of oilseeds. The optimum dose of phosphorous and plant growth regulators significantly enhanced oil content, protein content, grain yield, stover yield, and early setting of 50\% flowering and prolonged crop maturity besides significant improvement in the performance of various growth parameters, dry matter production, and quality parameters of oilseed crops.

\section{References}

1. Aberg B. Plant Growth Regulators. XLI: Monosubstituted Benzoic Acids. Swedish J Agric Res 1981;11:93-105.

2. AL-Jobori KM. Evaluation of the role of Gibberellin and Cytokinin in Regulation of Seed Setting and Seed Filling in Sunflower plant (Helianthus annuus L.). Diyala Journal for Pure Science 2012;8(4):60-79. 
3. Ankush KR. Effect of Growth Regulators on Seed Filling in Sunflower during Kharif Season (Doctoral dissertation, Mahatma Phule Krishi Vidyapeeth, Rahuri.). International Journal of Chemical Studies 2012; 6(6):1212-1214.

4. Bastani S, Hajiboland R. Uptake and utilization of applied phosphorus in oilseed rape (Brassica napus L. cv. Hayola) plants at vegetative and reproductive stages: Comparison of root with foliar phosphorus application. Soil Science and Plant Nutrition 2017;63(3):254-263.

5. Begum F, Hossain F, Islam M, Mondal M, Islam R. Effect of Naphthalene Acetic Acid (NAA) on Oil Content and Quality of the Mustard Plant (Brassica campestries L.). Pertanika Journal of Tropical Agricultural Science 2018; 41(1).

6. Behera S, Padhiary AK, Rout S, Nayak A, Behera D, Nanda PK. Effect of Plant Growth Regulators on Morpho-Physiological and Yield Parameters of Some Sesame (Sesamum indicum L.) Cultivars. Int J Curr Microbiol App Sci 2017;6(11):1784-1809.

7. Chorey AB, Thosar VR. Effect of individuals production factors on yield of rabi sunflower. Research JournalPunjabrao Krishi Vidyapeeth 1997;21:169-170.

8. Chute KH, Deotale RD, Jadhav GN, Meshram SD. Influence of Cow Urine and NAA on Chemical, Biochemical and Yield Contributing Parameters and Yield of Linseed 2017.

9. Cutt J, Klessing D. Salicylic acid in plants--a changing perspective. Pharmaceutical Technology. Pharmaceut Technol 1992;16:26-34.

10. Dawood MG, Sadak MS, Bakry BA, El Karamany MF. Comparative studies on the role of benzoic, $t$-cinnamic, and salicylic acids on growth, some biochemical aspects, and yield of three flax cultivars grown under sandy soil conditions. Bulletin of the National Research Centre 2019;43(1):112.

11. Dhage SJ, Patil VD, Patange MJ. Effect of various levels of phosphorus and sulphur on yield, plant nutrient content, uptake and availability of nutrients at harvest stages of soybean [Glycine $\max$ (L.)]. International Journal of Current Microbiology and Applied Sciences 2014;3(12):833-844.

12. Du H, Ahmed F, Lin B, Li Z, Huang Y, Sun G, Gao Z. The effects of plant growth regulators on cell growth, protein, carotenoid, PUFAs and lipid production of Chlorella pyrenoidosa ZF strain. Energies 2017;10(11):1696.

13. El-Sabagh A, Abdelaal KA, Barutcular C. Impact of antioxidants supplementation on growth, yield and quality traits of canola (Brassica napus L.) under irrigation intervals in North Nile Delta of Egypt. Journal of Experimental Biology and Agricultural Sciences 2017;5(2):163-172.

14. Fariduddin Q, Hayat S, Ahmad A. Salicylic acid influences net photosynthetic rate, carboxylation efficiency, nitrate reductase activity, and seed yield in Brassica juncea. Photosynthetica 2003;41(2):281-284.

15. Gaydou EM, Arrivets J. Effects of phosphorus, potassium, dolomite, and nitrogen fertilization on the quality of soybean. Yields, proteins, and lipids. Journal of Agricultural and Food Chemistry 1983;31(4):765-769.

16. Gunes A, Inal A, Alpaslan M, Eraslan F, Bagci EG, Cicek N, et al. Salicylic acid induced changes on some physiological parameters symptomatic for oxidative stress and mineral nutrition in maize (Zea mays L.) grown under salinity. Journal of Plant Physiology 2007;164(6):728-736.

17. Gupta S, Meena MK, Datta S. The Alleviating Effect of Salicylic Acid on Early Seedling Growth of Soybean under Zinc and Lead Stress. Bull Env Pharmacol Life Sci 2017;6:48-54.

18. Hawkesford M, Horst W, Kichey T, Lambers $H$, Schjoerring J, Møller IS et al. Functions of macronutrients. In Marschner's mineral nutrition of higher plants (pp. 135-189). Academic Press 2012.

19. Hayat S, Ahmad A. (Eds.). Salicylic acid-a plant hormone. Springer Science \& Business Media 2007, P114.

20. Henry JL, Slinkard AE, Hogg TJ. The effect of phosphorus fertilizer on establishment, yield and quality of pea, lentil and faba bean. Canadian journal of plant science 1995;75(2):395-398.

21. Jadhav SH, Bhamburdekar SB. Effect of salicylic acid on germination performance in groundnut. Int $\mathbf{J}$ Appl Biol Pharm Technol 2011;2:224-227.

22. Khan MIR, Fatma M, Per TS, Anjum NA, Khan NA. Salicylic acid-induced abiotic stress tolerance and underlying mechanisms in plants. Frontiers in plant science 2015;6:462.

23. Khanam M, Islam MS, Ali MH, Chowdhury IF, Masum SM. Performance of soybean under different levels of phosphorus and potassium. Bangladesh Agronomy Journal 2016;19(1):99-108.

24. Khaswa SL, Dubey RK, Singh S, Tiwari RC. Growth, productivity and quality of soybean [Glycine $\max (\mathrm{L})$ Merrill) under different levels and sources of phosphorus and plant growth regulators in sub humid Rajasthan. African Journal of Agricultural Research 2014;9(12):1045-1051.

25. Kiddle GA, Doughty KJ, Wallsgrove RM. Salicylic acidinduced accumulation of glucosinolates in oilseed rape (Brassica napus L.) leaves. Journal of Experimental Botany 1994;45(9):1343-1346.

26. Kumar PP, John SA. Effect of plant growth promoters and growth retardants on growth parameters of mustard (Brassica juncea L.). Journal of Pharmacognosy and Phytochemistry 2018;7(3):2871-2873.

27. Kumar S, Wani JA, Lone BA, Singh P, Dar ZA, Qayoom $\mathrm{S}$ et al. Effect of different levels of phosphorus and sulphur on seed \& stover yield of soybean (Glycine max L. Merill) under 'Eutrochrepts'. Asian Research Journal of Agriculture 2017, P1-7.

28. Lende NS, Patil HM, Patil YJ, Borole DN, Zade BG. Effect of different levels of nitrogen and phosphorus on growth and yield of niger (Guizotia abyssinica L. Cass). International Journal of Chemical Studies 2017;5(5):2379-2382.

29. Malhotra H, Sharma S, Pandey R. Phosphorus nutrition: plant growth in response to deficiency and excess. In Plant Nutrients and Abiotic Stress Tolerance (pp. 171190). Springer, Singapore 2018.

30. McKevith B. Nutritional aspects of oilseeds. Nutrition Bulletin 2005;30(1):13-26.

31. Minakshi N, Deotale RD, Jaybhaye VR, Chinmalwar YA, Surywanshi VJ, Pandey BB et al. Effect of different concentrations of humic acid and NAA on morphophysiological parameters and yield of linseed. Journal of Soils and Crops 2017;27(1):88-94. 
32. Mohammadreza S, Amin B, Forogh A, Hossin M, Sorayya S. Response of Brassica napus L grains to the interactive effect of salinity and salicylic acid. Journal of Stress Physiology \& Biochemistry 2012;8(2).

33. Mouri SJ, Sarkar MAR, Uddin MR, Sarker UK, Hoque MMI. Effect of variety and phosphorus on the yield components and yield of groundnut. Progressive Agriculture 2018;29(2):117-126.

34. Muhal S, Solanki NS, Singh P, Shukla KB. Effect of salicylic acid on productivity and nutrient uptake of Brassica species under different planting durations. African Journal of Agricultural Research 2014;9(13):1101-1106.

35. Muthulakshmi S, Lingakumar K. Role of salicylic acid (SA) in plants. International Journal of Applied Research 2017;3(3):33-37.

36. Nazar R, Iqbal N, Syeed S, Khan NA. Salicylic acid alleviates decreases in photosynthesis under salt stress by enhancing nitrogen and sulfur assimilation and antioxidant metabolism differentially in two mungbean cultivars. Journal of plant physiology 2011;168(8):807815.

37. Nazar R, Umar S, Khan NA, Sareer O. Salicylic acid supplementation improves photosynthesis and growth in mustard through changes in proline accumulation and ethylene formation under drought stress. South African Journal of Botany 2015;98:84-94.

38. Oad FC, Qayyum SM, Oad NL, Gandahi AW, Sohu GN, Chandio GQ. Effect of Various NPK Fertilizer Doses on the Growth, Seed Yield and Oil Content of Brassica. JApSc 2001;1(3):377-378.

39. Patel PK, Kadivala VAH, Patel VN. Role of Sulphur in Oilseed Crops: A Review. Journal of Plant Development Sciences 2019;11(3):109-114.

40. Raj B, Singh T, Singh H. Genotypes, irrigation and fertility effects on seed yield, water use and water-use efficiency of spring sunflower (Helianthus annuus). The Indian Journal of Agricultural Sciences 1999;69(2).

41. Raskin I. Role of salicylic acid in plants. Annual review of plant biology 1992;43(1):439-463.

42. Sarwar MF, Sarwar MH, Sarwar M, Qadri NA, Moghal $\mathrm{S}$. The role of oilseeds nutrition in human health: A critical review. Journal of Cereals and oilseeds 2013;4(8):97-100.

43. Sharma N, Khan AH, Nehal N, Singh M, Singh Y. Effect of PGRS on phenology and biochemical changes of mustard [Brassica juncea (L.) Czern. \& Coss.]. Journal of Pharmacognosy and Phytochemistry 2018;SP2:57-59.

44. Sharma R, Singh G, Sharma K. Effect of triacontanol, mixatol and NAA on yield and it's components in mung bean. Indian J agric 1989;3(1):59-60.

45. Siddik A, Shirazy BJ, Islam MM, Hoque A, Haque M. Combined effect of nitrogen and NAA on the yield of Sesame (Sesamum indicum L.). Scientia 2016;13(1):1-9.

46. Syers JK, Johnston AE, Curtin D. Efficiency of soil and fertilizer phosphorus use. FAO Fertilizer and plant nutrition bulletin 2008;18(108).

47. Thavaprakash N, Kumar SS, Raja K, Kumar GS. Effect Of Nitrogen And Phosphorus Levels And Ratios on Seed Yield And Nutrient Uptake of Sunflower Hybrid DshI/La Influencia De Diferentes Cantidades Y Proporciones De Nitrógeno Y De Fósforo En La Adopción De Las Materias Nutritivas En Híbridos/Effet De Différentes Quantités Et Proportions D'azote Et De Phosphore Sur
L'absorption De Matières Nutritives Par L'hybride De Tournesol (DSH-1). Helia 2002;25(37):59-68.

48. Ullah F, Bano A, Nosheen A. Effects of plant growth regulators on growth and oil quality of canola (Brassica napus L.) under drought stress. Pak J Bot 2012;44(6):1873-1880.

49. Vance CP, Uhde-Stone C, Allan DL. Phosphorus acquisition and use: critical adaptations by plants for securing a non-renewable resource. New phytologist 2003;157(3):423-447.

50. Win M, Nakasathien S, Sarobol E. Effects of phosphorus on seed oil and protein contents and phosphorus use efficiency in some soybean varieties. Kasetsart J Nat. Sci 2010;44:1-9.

51. Yadav P, Meena HP, Ramesh K. Effect of soil fertigation on oil content and oil quality of oilseed crops 2018.

52. Yamamoto M, Yamamoto KT. Differential effects of 1naphthaleneacetic acid, indole-3-acetic acid and 2, 4dichlorophenoxyacetic acid on the gravitropic response of roots in an auxin-resistant mutant of Arabidopsis, auxl. Plant and Cell Physiology 1998;39(6):660-664.

53. Youssef RA, El-Azab ME, Mahdy HA, Essa EM, Mohammed KA. Effect of salicylic acid on growth, yield, nutritional status and physiological properties of sunflower plant under salinity stress. International Journal of Pharmaceutical and Phytopharmacological Research 2017;7(5):54-58. 